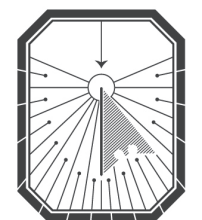

KYIV-MOHYLA

LAW \& POLITICS JOURNAL

KYIV-MOHYLA SCHOLARLY PEER-REVIEWED JOURNALS

Ukraine`s National Policy on Aquaculture: Reality or Myth?

Author(s): Oleksiy Kononov

Source: Kyiv-Mohyla Law and Politics Journal 6 (2020): 73-106

Published by: National University of Kyiv-Mohyla Academy

http://kmlpj.ukma.edu.ua/ 


\title{
Ukraine's National Policy on Aquaculture: Reality or Myth?
}

\author{
Oleksiy Kononov \\ Independent legal researcher \\ Ukraine
}

\begin{abstract}
Aquaculture is a promising sector in Ukraine's agricultural economy and could contribute to the nation's food security and assist in overcoming some of the challenges posed by the COVID-19 pandemic. For years, Ukrainian government's policy towards aquaculture has been less than supportive, in part because the government's management of the sector has been tossed between different ministries. Legal regulation of the sector is overcomplicated, and producers face numerous difficulties with permits, rent of waterbodies, inspections, customs, and feed importation. There are no specific approximation obligations related to aquaculture in the Association Agreement between the European Union and Ukraine. State aid to struggling aquaculture producers remains insignificant and difficult to get compared to the aid available to other agricultural businesses. This article analyzes the main policy and legal problems faced by aquaculture businesses in Ukraine and concludes with solutions that can improve the situation.
\end{abstract}

Key Words: agriculture, aquaculture, COVID-19 responses, fisheries, state aid, water resources

\section{讨}

\section{Introduction}

The COVID-19 pandemic has led to dramatic loss of human life across the world and presents an unprecedented challenge with deep social and economic consequences including compromising food security and nutrition. Responses need to be well coordinated across the world, including by the G2o and beyond, to limit impacts, end the pandemic, and prevent its recurrence. ${ }^{1}$

The United Nations' recommendations for responding to the COVID-19 pandemic urge states to take all available national and international measures to meet the world's food and nutrition needs. For many years Ukraine has been one of the world's

1 Joint Statement on COVID-19 Impacts on Food Security and Nutrition (FAO, IFAD, the World

Bank and WFP on the occasion of the Extraordinary G2O Agriculture Minister's Meeting,

April 20, 202O), accessed April 30, 2020, http://www.fao.org/news/story/en/item/1272058/icode/. 
largest exporters of agricultural commodities. In particular, according to the Food and Agriculture Organization of the United Nations (FAO), Ukraine is one of the world leaders exporting sunflower oil, corn, maize, wheat, barley, and soybeans. ${ }^{2}$ The nation's nickname "The Granary of Europe" is well-deserved. But does this automatically mean the country is using all available opportunities to satisfy both its national and the world's food demand with its agricultural output and to create more possibilities for local businesses? The answer is no. When talking about Ukraine's agriculture, one would first think of growing crops and, to a lesser extent, of chicken, sugar, honey, and tobacco production. Some sectors remain virtually unknown either abroad or domestically. One of these "unknown" agricultural sectors is aquaculture.

The Law of Ukraine on Aquaculture of September 18, $2012^{3}$ defines "aquaculture" as:

agricultural activities for artificial breeding, keeping and growing objects of aquaculture in whole or in part in controlled conditions for aquaculture and feed production, reproduction of biological resources, conducting selection and breeding work, introduction, resettlement, acclimatization and re-acclimatization of aquatic organisms, replenishment of water biological resources, preservation of biodiversity and recreational services. ${ }^{4}$

In other words, not to be confused with fishing (harvesting fish and other aquatic organisms), aquaculture means fish breeding, sometimes also referred to as fish farming. In practical terms, aquaculture businesses provide customers with fish and various seafoods specifically grown for their purposes.

Ukraine used to be a renowned producer of aquaculture products. Before 1917, oysters grown on the Black Sea oyster farms in thesouthern provinces of the Russian Empire (the modern territory of Crimea, Odesa, Mykolaiv and Kherson regions of Ukraine) were known throughout Europe. ${ }^{5}$ During the Soviet era, Ukraine's aquaculture performance was outstanding. "Aquaculture in Ukraine was one of the most developed among the Soviet republics. Ukraine had all the elements for fish and seafood production, including fishing and fish processing, reproduction and protection of fish

FAOSTAT: Commodities by Country (Exports), accessed April 30, 2020, http://www.fao.org/ faostat/en/\#rankings/commodities_by_country_exports.

Zakon Ukrainy "Pro akvakulturu" vid 18 veresnia 2012 roku z nastupnymy zminamy

i dopovnennyamy [Law of Ukraine on Aquaculture of September 18, 2012 as amended], accessed April 30, 2020, https://zakon.rada.gov.ua/laws/show/5293-17, article 1(1).

$4 \quad \operatorname{Article} 1(1)$.

5 Kostyantyn Symonenko, "Yakv Ukrayini vidkryty ustrychnu fermu [How to Open an Oyster Farm in Ukraine]" (May 15, 2017), accessed April 30, 2020, https://news.finance.ua/ua/news/-/401586/ yak-v-ukrayini-vidkryty-ustrychnu-fermu. 
stocks, fish breeding centres. The level of productivity of fish-breeding ponds exceeded the average figure in the Soviet Union." ${ }^{\prime 6}$

In 1988, Ukraine's aquaculture output was more than 96,ooo metric tons, and, along with the fishing catches, the republic was able to satisfy the domestic demand. Aquaculture output began to drop rapidly from 1990 onwards, and today more than 80 per cent of fish and seafood for domestic needs are imported. The table below displays the production output data for Ukraine compared to the same for Poland and Turkey.

Table 1. Aquaculture outputs (metric tons) in Ukraine, Poland, and Turkey ${ }^{7}$

\begin{tabular}{|c|c|c|c|c|c|c|c|}
\hline YEAR & 1988 & 1990 & 1991 & 1992 & 1998 & 2011 & 2012 \\
\hline UKRAINE & 96182 & 81639 & 54648 & 66904 & $2833^{2}$ & 23553 & 23720 \\
\hline POLAND & $2595^{1}$ & 26400 & 29500 & 30200 & 29791 & 29037 & 32261 \\
\hline TURKEY & 4100 & 5782 & 7835 & 9085 & $5^{6} 700$ & 188890 & 212805 \\
\hline YEAR & 2013 & 2014 & 2015 & 2016 & 2017 & 2018 & 2019 \\
\hline UKRAINE & 23175 & 24434 & 22241 & 21425 & 20168 & 20192 & $186 \circ 3$ \\
\hline POLAND & 35208 & 40110 & 36971 & 38300 & 38800 & no data & no data \\
\hline TURKEY & 233864 & 234302 & 238964 & 250331 & 273477 & no data & no data \\
\hline
\end{tabular}

The figures speak for themselves. Aquaculture business representatives, however, add that in 1986, the Donetsk Fishery Plant alone produced about 13,500 tons of fish

6 Aquaculture Development in Ukraine: Comprehensive Analysis of Challenges and Opportunities of Aquaculture Industry in Ukraine, Best-Practice Experience and Policy Recommendations (Kyiv: EasyBusiness, Norwegian-Ukrainian Chamber of Commerce, Everlegal, State Fisheries Agency of Ukraine, 2017), 9, accessed April 30, 2020, https://www.slideshare.net/Easy_Business/ aquaculture-development-in-ukraine-83657826.

7 Data for 1988-2017 is based on the FAO's "Global Aquaculture Production (online query)," accessed April 30, 2020, http://www.fao.org/fishery/statistics/global-aquaculture-production/ query/en; Ukraine's figures for 2018 and 2019 provided based on the statistics of the State Agency of Fisheries of Ukraine, see "Produktsiia akvakultury za 2018 rik (Zvit 1-A (Ryba richna)) [Aquaculture Production in 2018" (Report 1-A (River Fish)]" and "Produktsiia akvakultury za 2019 rik (Zvit 1-A (Ryba richna)) [Aquaculture Production in 2019 (Report 1-A (River Fish)],"accessed April 30, 2020, http://darg.gov.ua/_virobnictvo_produkciji_o_223_menu_o_1.html. 
and seafood. ${ }^{8}$ Since then, total Ukrainian outputs have been only modestly higher than that single plant's output and have been substantially less than those of Poland for about a decade.

This decline can be partially explained by the end of the USSR's generous state aid to fishery and aquaculture production after Ukraine declared its independence. General economic problems and irregularities and the controversial privatization of numerous aquaculture farms and fishing plants also contributed to the sector's rapid decline. In addition, unlike most other former Soviet Bloc countries, Ukraine neither restructured the sector nor shifted from Soviet style to modern management practices.

The loss of Crimea in 2014 substantially impacted Ukraine's fisheries sector, causing catches to plummet by 60 per cent. ${ }^{9}$ But, as Table 1 shows, aquaculture was not affected. Even without Crimea, Ukraine has significant natural resources. Inland waters (rivers, ponds, lakes, reservoirs) total 1.3 million hectares, the largest total of any European country. And marine waters in the Black Sea and the Sea of Azov total 9.1 million hectares. ${ }^{10}$ Pond-based aquaculture ${ }^{11}$ has a long tradition in Ukraine. It alone can produce 163,00o tons of aquaculture products annually. If used intensively, production in these waters might reach 400,ooo tons, almost double Turkey's aquaculture output. ${ }^{12}$ Thus, Ukraine can potentially become one of the regional leaders in aquaculture production. However, according to the State Agency for Fisheries of Ukraine, only $67,873.1$ hectares of those inland water resources were used for aquaculture as of late 2018 , with only 26 kilos of fish grown per hectare. Because the fish capacity of inland water resources is 3 centner/hectare, comparing actual with potential production shows that water resources are being used inefficiently. ${ }^{13}$ Today's aquaculture in Ukraine is mostly pond-based and produces mainly such species as European carp, phytophagous fishes, various indigenous fishes (sterlet, salmon, and some predator species). ${ }^{14}$

What accounts for this rather pitiful situation? Is it only the lack of the state's financial investments or is there more? To see a broader picture, to answer these

"Khto zupynyt derzhavny reket u rybnytstvi? [Who Will Stop State Racketeering in Fisheries?]," interview by Yuriy Yaremenko, AgroNews.ua, January 18, 2019, accessed April 30, 2020, https:// agronews.ua/interview/kKhto-zupynyt-derzhavny-reket-u-rybnytstvi/.

9225 , Ooo tons in 2013 (including Crimea) to 91,ooo tons in 2014 (without Crimea), see "Reforms to Increase Production, Streamline Administration", Eurofish Magazine, 2016, no. 1, 34.

10 Aquaculture Development in Ukraine, 11; "Reforms to Increase Production, Streamline Administration," ibid.

11 Article 13 of the Law on Aquaculture distinguishes between the land-based, cage-based and pond-based aquaculture.

12 Aquaculture Development in Ukraine, 23.

13 Ibid, 9-11, 23.

14 Publichnyi zvit Derzhavnoho ahentstva rybnoho hospodarstva za 2019 rik [Public Report of the State Agency of Fisheries of Ukraine for 2019], at 5, 6, accessed May 6, 2020, https://www.kmu. gov.ua/storage/app/sites/1/17-civik-2018/zvit_2019/zvit-2019-fish.pdf. 
questions, and to provide some of the possible solutions, this article will focus on the following problems:

1) aquaculture is not perceived by the state as a priority sector of agriculture;

2) overcomplicated legal regulation and untransparent system of permits;

3) customs problems, expensive feed and absence of capital for development; and

4) complications in getting state aid. ${ }^{15}$

\section{(1) Aquaculture Is Not Perceived by the State as a Priority Sector of Agriculture}

In 2018 aquaculture accounted for only 0.3 percent of Ukraine's agricultural production. ${ }^{16}$ Therefore, that the sector is virtually unknown even domestically is not surprising. Along with the state's rather specific attitude to environmental problems and existing inefficiencies in protection, use and monitoring of water resources, life of aquaculture businesses is not getting any easier.

In February 2019, the Verkhovna Rada of Ukraine adopted the Fundamentals (Strategy) of the State Environmental Policy of Ukraine until 2030.17 The Strategy mentions the necessity of introducing the efficient management of water resources, but the language is declaratory. In January 2020, the Ukrainian Parliament issued Recommendations of Parliamentary Hearings on Priorities of Environmental Policy of Verkhovna Rada of Ukraine for the Following Five Years. ${ }^{18}$ Mentioning water resources in the recommendations, the parliament stressed the necessity to clarify and specify the Strategy's provisions "by means of its systematization by each natural resource providing the conformity with the ecological systemacy approach,"19 and also stressed

15 Main Problems Regularly Raised by Representatives of Aquaculture Industry, see ibid, 11, 24-30; Yaremenko Yu. F., "Rybav sitkah biurokrata [Fish in Bureaucrat's Nets],"Ekonomichna Pravda, August 15, 2019, accessed April 30, 2020, https://www.epravda.com.ua/ columns/2019/o8/15/650548/; Sharylo Yu. Ye., "Problemy rozvytku suchasnoyi akvakultury [Problems for Development of Modern Aquaculture],"accessed April 30, 2020, https://www. slideshare.net/USAIDLEV/ss-64585413.

16 Aquaculture Development in Ukraine, 6.

17 Zakon Ukrainy "Pro osnovni zasady (strategiiu) derzhavnoi ekologichnoi polityky Ukrainy na period do 203 o roku" [The Law of Ukraine on the Fundamentals (Strategy) of the State Environmental Policy of Ukraine Until 2030], Vidomosti Verkhovnoi Rady Ukrainy, 2019, No. 16, St. 70 .

18 Rekomendatsii parlamentskykh slukhan na temu: "Priorytety ekolohichnoi polityky Verkhovnoi Rady Ukrainy na nastupni piat rokiv," zatverdzheni postanovoiu Verkhovnoi Rady Ukrainy vid 14 sichnia 2020 roku No. 457-IX [Recommendations of Parliamentary Hearings on the Topic "Priorities of Environmental Policy of Verkhovna Rada for the Following Five Years" approved by the Resolution of Verkhovna Rada of Ukraine of January 14, 2020 No. 457-IX], accessed May 2, 2020, https://zakon.rada.gov.ua/laws/show/457-20. 
the necessity of achieving the goals in the Association Agreement between the European Union and Ukraine. ${ }^{20}$

The parliamentary talk of "systemacy" looks weird considering earlier developments taken at the initiative of the new Ukrainian Cabinet of Ministers. In September 2019, the Cabinet of Ministers decided to "optimize" some of the ministries, including those responsible for environmental policies and agriculture. In particular, the Ministry of Agrarian Policy and Food of Ukraine was absorbed into the Ministry for Development of Economy, Trade and Agriculture, and the Ministry of Ecology and Natural Resources was combined with the Ministry of Energy and Coal Industry under the name "Ministry of Energy and Environmental Protection of Ukraine." ${ }^{21}$ The potential gains from combining energy and the environment within a ministry is beyond the scope of this article. But the reorganized Ministry of Energy and Environmental Protection (MEEP)is now responsible for the formation and implementation of the state's policy concerning fisheries and fishing, the protection, use, and restoration of water biological resources, the regulation of fishing, and the safety of navigation of the fishing fleet, forest, and hunting industries. ${ }^{22}$ In the meantime, the reformed Ministry for Development of Economy, Trade and Agriculture (MDETA) will be responsible for Ukraine's agricultural sector. ${ }^{23}$ The reorganization of the two ministries left conflicting provisions in their respective charters regulating the scope of their authority. The MDETA remains the central executive body responsible for fisheries, ${ }^{24}$ while the MEEP is responsible for the "formation and implementation of the state policy" in the field of fisheries (aquaculture included). ${ }^{25}$ It is not quite clear how to distinguish the two, yet the two state agencies (the State Water Resources Agency and the State Agency of

20 Ibid; Association Agreement between the European Union and its Member States, of the one part, and Ukraine, of the other part, of 21 March 2014 (2014) OJ L 161, 3.

Postanova Kabinetu Ministriv Ukrainy vid 2 veresnya 2019 r. No. 829 "Deyaki Pytannya Optymyzatsiyi Systemy Tsentralnykh Orhaniv Vykonavchoyi Vlady" z nastupnymy zminamy i dopovnennyamy [Resolution of the Cabinet of Ministers of Ukraine of September 2, 2019 No. 829 on Some Issues Related to Optimization of Central Bodies of Executive Power as amended], accessed May 2, 2020, https://zakon.rada.gov.ua/laws/show/829-2019-\%Do\%BF. Para 1 of the MEEP Charter, see Polozhennya pro Ministerstvo enerhetyky ta zakhystu dovkillya Ukrainy v redaktsiyi postanovy Kabinetu Ministriv Ukrainy vid 18 veresnya 2019 r. No. 847 [Charter of the Ministry of Energy and Environmental Protection of Ukraine as amended by the Resolution of the Cabinet of Ministers of Ukraine of September 18, 2019 No. 847], OfitsiynyiVisnykUkrainy, 2019, No. 78, St. 2694.

Paras 1-3 of the MDETA Charter, see Polozhennya pro Ministerstvo rozvytku ekonomiky, torhivli ta silskogo hospodarstva Ukrainy v redaktsiyi postanovy Kabinetu Ministriv Ukrainy vid 11 veresnya 2019 r. No. 838 [Charter of the Ministry for Development of Economy, Trade and Agriculture as amended by the Resolution of the Cabinet of Ministers of Ukraine of September 11, 2019 No. 838], Ofitsiynyi Visnyk Ukrainy, 2019, No. 74, St. 2588. 
Fisheries) essential for aquaculture production were transferred under MEEP's control. In practical terms this means that aquaculture producers have to deal with MEEP rather than MDETA since those two state agencies are crucial for their business activities. ${ }^{26}$ The very fact that aquaculture production is now subordinated to MEEP is not only weird for observers but is heavily criticized by those who insist that agriculture should be treated as a whole by one ministry without excluding aquaculture. They summarize their discontent by using a phrase "the new ministry will deprive aquaculture of all energy." ${ }^{27}$ In the context it has to be noted that, after the submission of this article for publication, the Cabinet of Ministers of Ukraine recognized the mistakes and adopted a resolution to split MEEP into the Ministry of Energy and the Ministry of Environmental Protection and Natural Resources. ${ }^{28}$ It remains to be studied how that change impacted the aquaculture industry and how the industry dealt with the abrupt changes, subsequent new appointments within the Government and problems related thereto (if any).

Parliament's references to the Association Agreement in the Recommendations do not automatically mean that Ukrainian aquaculture producers can hope for improvements based on the rules existing in the European Union (EU) acquis. The Association Agreement provides that Ukraine and the EU will cooperate on water quality and water resource management, including the marine environment. ${ }^{29}$ Ukraine committed itself to the gradual approximation of Ukrainian legislation to the EU acquis on the environment consistently with the annexes to the Association Agreement. ${ }^{30}$ According to the Governmental Office for Coordination on European and Euro-Atlantic Integration and as of this writing, 47 per cent of Ukraine's obligations relating to environmental protection and civil defense have been fulfilled. ${ }^{31}$ But Ukraine's aquaculture industry can hardly benefit from that performance; the Association

26 In particular, aquaculture producers must report on outputs, sales, water resources used in the production cycle to the State Agency of Fisheries of Ukraine, the latter also deals with matters related to fishing per se; use of water resources is impossible without approvals issued by the State Water Resources Agency.

27 Yaremenko Yu. F., "Nove ministerstvo pozbavyt akvakulturu enerhetyky [New Ministry Will Deprive Aquaculture of Energy]," Agro Times, October 19, 2019, accessed May 2, 2020, https:// agrotimes.ua/opinion/nove-ministerstvo-pozbavyt-akvakulturu-energetyky/. See Deiaki pytannia optymizatsii systemy tsentralnykh organiv vykonavchoi vlady vid 27 travnia 2020 roku No. 425 [Some Issues of Optimization of the System of Central Bodies of Executive Power adopted by the resolution of the Cabinet of Ministers of Ukraine of May 27, 2020 No. 425], Ofitsiynyi Visnyk Ukrainy, 2020, No. 45, St. 1449.

29 Article 361 AA.

30 Article 363 AA.

$31 \quad$ Puls Uhody: monitorynh realizatsii planu zakhodiv z vykonannia Uhody (navkolyshne pryrodne seredovyshche ta tsyvilnyi zahyst) [Pulse of the Agreement: Monitoring of the Compliance with the Association Agreement Implementation Plan (Environment and Civil Defense), accessed May 2, 2020, http://reforms.in.ua/ua/streams/environment. 
Agreement does not contain any obligations that would benefit the industry and help it solve some of the specific problems briefly described below. Ukraine's lack of "noticing" aquaculture as such can also be traced in other parts of the Association Agreement. "Aquaculture" is mentioned in the text only in the context of aquaculture diseases. It is not mentioned in the Association Agreement's sections devoted to agriculture or fisheries; Ukraine is not obligated to implement any acquis on the common fisheries policy.

\section{(2) Overcomplicated Legal Regulation of Aquaculture Production, Untransparent System of Permits}

The aquaculture industry is heavily regulated. As will be shown below, the existing regulation is overcomplicated. There are numerous conflicting provisions and gaps that create endless possibilities for abuses and corruption. It would be impossible to analyze them all within the framework of this article. This article therefore will focus on the most important ones frequently mentioned by aquaculture businesses:

- general difficulties related to the existence of numerous bureaucratic procedures depending on a specific type of aquaculture in question;

- difficulties related to the use of water bodies and aquatic biological resources for the needs of aquaculture; and

- difficulties related to veterinary inspections and food-safety permits.

The Law of Ukraine on Aquaculture is the core law for the industry. It applies to aquaculture activities carried out in inland waters, fishery water bodies, internal seas, territorial seas, and the exclusive economic zone of Ukraine, as well as on land areas used for aquaculture. It defines aquaculture and divides it into land-based, cage-based, and pond production. ${ }^{32}$ Each category is subject to specific permitting and licensing requirements. No single and transparent procedure for issuing such permits exists as of this article's writing. For example, permits for business activities in the water sector to use water bodies are granted by local authorities based on the Water Code ${ }^{33}$ and Land Code. ${ }^{34}$ If a legal entity or an individual wants to use fishery technological reservoirs (floating units, mollusks collectors, water supply installations etc.) or parts of water objects, the Law on Aquaculture ${ }^{35}$ and the Land Code ${ }^{36}$ apply. If the internal

\footnotetext{
32 Articles 1, 13.

33 Art. 151 of the Water Code of Ukraine, see Vodnyi kodeks Ukrainy vid 6 chervnya 1995 roku z nastupnymy zminamy i dopovnennyamy [Water Code of Ukraine of June 6, 1995 as amended], accessed May 2, 2020, https://zakon.rada.gov.ua/laws/show/213/95-\%Do\%B2\%D1\%8o. 
sea waters of the territorial sea, the exclusive (maritime) economic zone are to be used by aquaculture producers, they must obtain permits from the Cabinet of Ministers of Ukraine. ${ }^{37}$

Before any permits for business activities can be granted, all water bodies and fishery technological reservoirs must have a passport. ${ }^{38}$ The landlord has the duty to obtain the passport according to the Order of the Ministry of Ecology and Natural Resources of Ukraine of March 18, 2013 No. 99 on Approval of the Procedure of Water Object's Passport Development. ${ }^{39}$ If water objects such as fishery technological reservoirs, a land plot under the fishery technological reservoir, and hydrotechnical constructions are rented, the tenant must obtain passports for them based on a different set of rules set out in the Order of the Ministry of Ecology and Natural Resources of December 16, 2013 No. 742 on Approval of the Procedure of Fishery Technological Reservoir Passport Development. ${ }^{40}$ These passports are issued by the State Water Resources Agency of Ukraine. The requirement to obtain such passports does not facilitate renting of water objects in any way. In practice, obtaining passports can take up to three months, and the process is infused with corruption. ${ }^{41}$

In addition to provisions of the Land Code and the Water Code, the Law on Aquaculture establishes the basics of the land lease, lease of water bodies, and lease of fishery technological reservoirs for the purposes of aquaculture. It also establishes the essential terms of the water bodies lease agreement. ${ }^{42}$ The Resolution of the Cabinet of Ministers of Ukraine on Approval of Standard Lease Agreement of Water Objects No. 420 of May 29, $2013^{43}$ leaves potential tenants with no alternative but to use the template's contract provisions.

37 Article 14 of the Law on Aquaculture, article 14 of the Water Code.

38 A document containing geographical description of a water object, indication of ownership and a right (rights) to use water resources of the object, technical parameters, purpose of use, limitations of use.

Nakaz Ministerstva ekologii ta pryrodnykh resursiv Ukrainy vid 18 bereznia 2013 roku No. 99 "Pro zatverdzhennia poriadku rozroblennia pasportu vodnoho obiektu" [Order of the Ministry of Ecology and Natural Resources of Ukraine of March 18, 2013 No. 99 on Approval of the Procedure of Water Object's Passport Development], accessed May 2, 2020, https://zakon.rada. gov.ua/laws/show/zo775-13.

$40 \quad$ Nakaz Ministerstva ekologii ta pryrodnykh resursiv Ukrainy vid 16 grudnia 2013 roku No. 742 "Pro zatverdzhennia poriadku rozroblennia pasporta rybohospodarskoi tekhnologichnoi vodoimy" [Order of the Ministry of Ecology and Natural Resources of Ukraine of December 16, 2013, No. 742 on Approval of the Procedure of Fishery Technological Reservoir Passport Development], accessed May 2, 2020, https://zakon.rada.gov.ua/laws/show/zoo27-14.

41 Aquaculture Development in Ukraine, 29.

42 Article 14.

43 Postanova Kabinetu Ministriv Ukrainy "Pro zatverdzhennya Typovoho dohovoru orendy vodnykh obiektiv" No. 420 vid 23 travnia 2013 roku z nastupnymy zminamy i dopovnennyamy [the Resolution of the Cabinet of Ministers of Ukraine on Approval of Standard Lease Agreement of 
The Law of Ukraine on Fisheries, Industrial Fisheries and Protection of Aquatic Biological Resources ${ }^{44}$ states that the use of aquatic biological resources that are isolated in natural or artificial water bodies for the purposes of aquaculture is not a special use of aquatic biological resources and shall be conducted in accordance with procedures established by the owners of such resources. ${ }^{45}$ Based on Article 42 of the Law, the State Water Resources Agency of Ukraine, which is subordinated to the Ministry of Energy and Environmental Protection, keeps the records on the fishery water bodies and their parts, fishery technological reservoirs, water areas, internal sea waters, territorial seas, and the exclusive maritime economic zone of Ukraine allocated for aquaculture. These records are created under the procedure established by the resolution of the Cabinet of Ministers of Ukraine on Approval of the State Register of Fishery Water Bodies (Their Parts) No. 979 of September 30, 2015.

Not many of the existing aquaculture businesses need an entire water body for aquaculture production and some cannot afford to lease an entire water body. The existing laws (the Water Code, the Law on Aquaculture in particular) permit using a part of a water body. However, in practice this is impossible. First, this is possible only if a part of the water body is used for fishery or to create a floating aquaculture farm (floating fish-breeding garden). ${ }^{46}$ When either occurs, the use of the parts of the water body for other purposes is forbidden. Second, current regulations are silent on the order of assignment for the use of a part of water body. In addition, it remains unclear how to site a water fund land plot underwater and to establish its boundaries though this is essential for signing a lease agreement. In 2018, the State Agency of Fisheries of Ukraine, in close cooperation with representatives of aquaculture producers, attempted to remedy this situation by drafting the necessary amendments to the Law on Aquaculture; the Water Code; the Land Code; the draft Resolution of the Cabinet of Ministers of Ukraine on Approval of the Procedure of Allocating for Use Based on Lease Agreements of Parts of Fishery Water Bodies for Purposes of Aquaculture, Water Space of Inland Sea Waters, Territorial Sea, Exclusive Economic Zone of Ukraine; and Siting Parts of Such Water Bodies for Purposes of Sea Aquaculture. ${ }^{47}$ Unfortunately, no amendment had been approved as of May 1, 2020.

There are numerous practical complications with land tenders, both for underwater plots and for those on the surface necessary for aquaculture. There are completely

Water Objects No. 420 of May 29, 2013 as amended], accessed May 2, 2O2O, https://zakon.rada. gov.ua/laws/show/420-2013-\%Do\%BF.

Zakon Ukrainy "Pro rybne hospodarstvo, promyslove rybalstvo ta okhoronu vodnykh bioresursiv" vid 8 lypnia 2011 roku z nastupnymy zminamy i dopovnenniamy [The Law of Ukraine on Fisheries, Industrial Fisheries and Protection of Aquatic Biological Resources of July 8, 2011 as amended], accessed May 2, 2020, https://zakon.rada.gov.ua/laws/show/3677-17.

45 Article 27.

46 Article $5^{1}$ of the Water Code of Ukraine, Article 14(1) of the Law on Aquaculture.

47 Publichyi zvit Derzhavnoho ahentstva rybnoho hospodarstva Ukrainy za 2018 rik [Public report of the State Agency of Fisheries of Ukraine for 2018], 3, accessed May 2, 2020, http://darg.gov. ua/_publichnij_zvit_derzhavnogo_o_o_o_8359_1.html. 
different mechanisms for the registration of a right to use different kinds of water bodies. Current legislation allows registration of ownership of Water Fund land plots not exceeding 3 hectares ${ }^{48}$ or of a right to use those plots based on lease contracts. ${ }^{49}$ Ukrainian laws sometimes provide for the possibility to draft different lease contracts for a water body, a land plot on which such water body is located, a hydraulic structure, and the like. The necessity to negotiate and conclude several different lease contracts is time-consuming and creates numerous possibilities for corruption. ${ }^{50}$ Allowing the signing a single lease contract along with amending the existing procedures for obtaining passports of water bodies could improve the situation.

Aquaculture businesses also complain about difficulties with the rent of water reservoirs for general-purpose use. The law allows local offices of the State Water Resources Agency of Ukraine to issue certificates for the right to use water reservoirs that are valid for $3^{-25}$ years. ${ }^{51}$ Because of inconsistent laws and regulations, however, only certificates valid for three years are issued. The costs for obtaining these certificates are high, and processing applications for them is time-consuming. ${ }^{52}$ The Water Code of Ukraine also contains "communist" provisions relating to the rights of citizens to use waters, including for fishing. ${ }^{33}$ In practical terms, this means that if an aquaculture producer rents a pond "within a populated area" and breeds fish there, a local resident can catch $3-5$ kilos of fish a day in that pond. ${ }^{54}$ Needless to say, this legally sanctioned poaching reduces the aquaculture producer's profits.

The Law of Ukraine on the Animal World ${ }^{55}$ designates fish and other objects of aquaculture as a part of the animal world. ${ }^{56}$ It also contains provisions on using water bodies for fishing, the rights and obligations of fish farming enterprises for using animals, the prevention of anthropogenic environmental pollution by aquaculture, and the prevention of the reduction of biological aquatic resources. ${ }^{57}$

The Law on Fish, Other Aquatic Biological Resources and Food Products from Them ${ }^{58}$ includes provisions related to the requirements for fish breeding and other

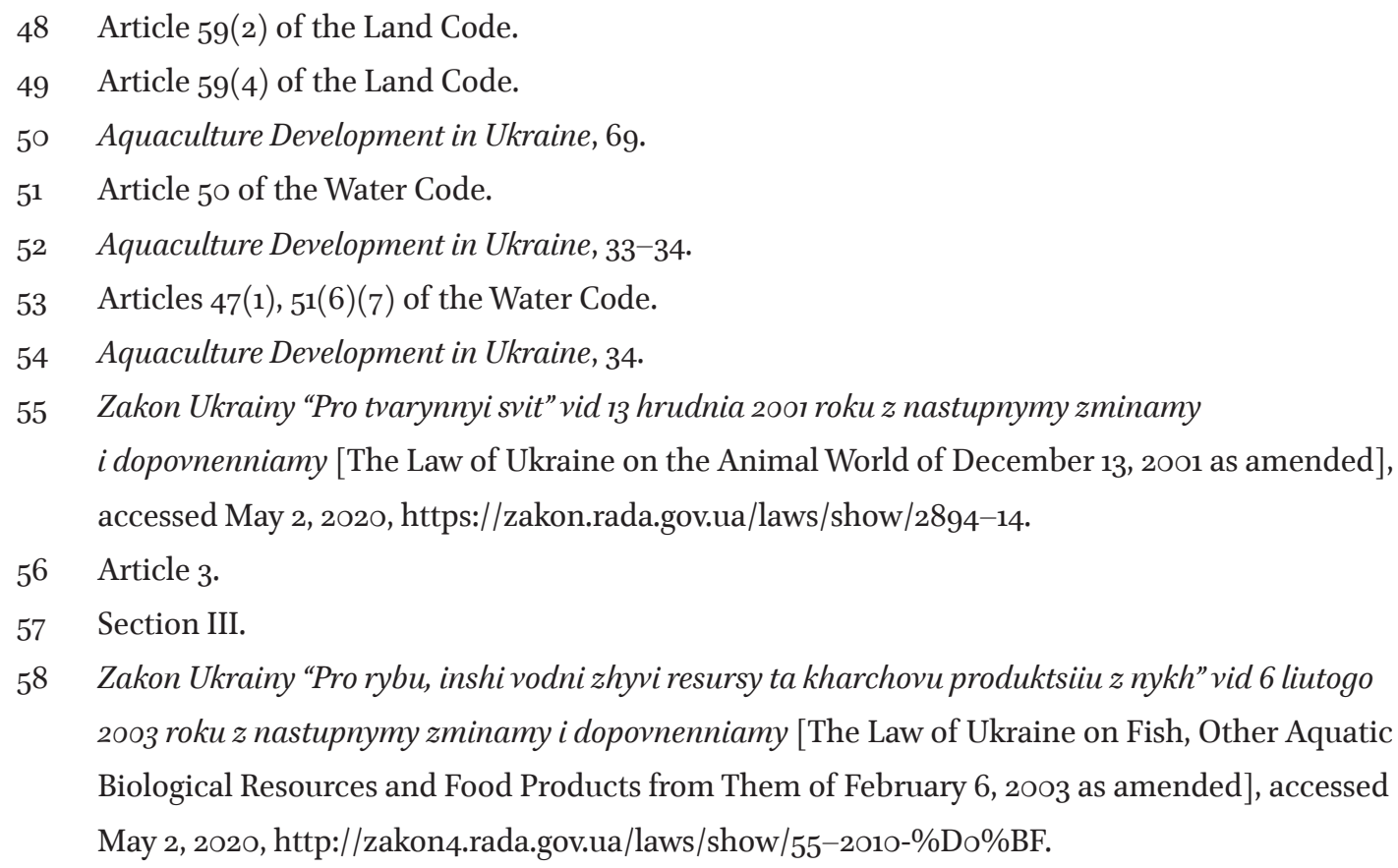


aquatic living organisms. These requirements establish that fish breeding and other aquatic living resources in fishery water bodies and their parts and in the continental shelf of Ukraine is permitted based on a positive evaluation of veterinary-sanitary condition of water bodies where such breeding is to be conducted. ${ }^{59}$ The quality and food safety of live fish and other aquatic living organisms that were grown in ponds and other water bodies or their is to be confirmed by a veterinary certificate. ${ }^{60}$

Procedures and conditions for obtaining these veterinary certificates as well as for obtaining a positive evaluation of veterinary-sanitary condition of water bodies are found in another law - the Law on Veterinary Medicine. ${ }^{61}$ That law also deals with the importation of fish into Ukraine, fertilized fish eggs and other hydrobionts for breeding, keeping and growing in terms of aquaculture, placing them in quarantine station, migration from quarantine stations to other fishery water bodies (parts thereof), fishery ponds and veterinary-sanitary control in aquaculture. ${ }^{62}$ Veterinary certificates and related permits are issued by the veterinary control bodies. Food safety certification of canned, frozen or otherwise cooked fish and other non-alive aquatic fish is done by the State Service of Ukraine on Food Safety and Consumer Protection based on the provisions of the Law of Ukraine on the State Control of Compliance with the Legislation on Foods, By-Products of Animal Origin, Health and Well-Being of Animals. ${ }^{63}$ There are elements that make the procedure extremely costly for Ukrainian producers. In particular, if a producer had grown 100 kilos of fish or other living aquatic organisms, to obtain the necessary veterinary certificates mentioned in Article 2(2) of the Law of Ukraine on Fish, Other Aquatic Biological Resources and Food Products from Them, he must give up 30 kilos to an authorized laboratory. Given that majority of aquaculture producers in Ukraine are small businesses, this amount is not scientifically based and causes significant financial losses. ${ }^{64}$

Another illustrative case happened when an aquaculture business in Odesa, after 10 years of heavy labor of growing sturgeon, finally managed to obtain 10 kilos of black caviar. To obtain the necessary certificate to be able to sell the caviar, the producer consulted a laboratory operated under the auspices of the State Service of Ukraine

\footnotetext{
59 Article 2.

6 Ibid.

$61 \quad$ Zakon Ukrainy "Pro veterynarnu medytsynu" vid 25 chervnia 1992 roku z nastupnymy zminamy i dopovnenniamy [The Law of Ukraine on Veterinary Medicine of June 25, 1992 as amended], accessed May 2, 2020, https://zakon.rada.gov.ua/laws/show/2498-12.

62 Articles 16, 18, 81, 84, 87, 95 .

63 Zakon Ukrainy "Pro derzhavnyi control za dotrymanniam zakonodavstva pro kharchovi produkty, pobichni produkty tvarynnoho pokhodzhennia, zdorovia ta blahopoluchchia tvaryn" vid 18 travnia 2017 roku z nastupnymy zminamy i dopovnenniamy [the Law of Ukraine on the State Control of Compliance with the Legislation on Foods, By-Products of Animal Origin, Health and Well-Being of Animals of May 18, 2017 as amended], accessed May 3, 2020, https://zakon.rada.gov. ua/laws/show/2042-19.

64 Aquaculture Development in Ukraine, 21, 71.
} 
on Food Safety and Consumer Protection. The lab demanded 3.5 kilos of caviar to conduct the examination. ${ }^{65}$ The problem lies in the existing Procedure on Selecting Specimen of Products of Animal, Plant and Biotechnical Origin for Examination approved by the Resolution of the Cabinet of Ministers of Ukraine No. 833 of June 14, 2002, the latter does not specify the number of fry or caviar necessary for examination, despite doing so for frozen and canned fish. Even after the adoption and entry into force of the new Law on the State Control of Compliance with the Legislation on Foods, By-Products of Animal Origin, Health and Well-Being of Animals back in 2017 the Procedure was not updated. ${ }^{66}$ Ukrainian law provides that where there are no nationally approved methodology for specimen collection and/or analysis, laboratories must use the methodology established by international organizations of which Ukraine is a member or by the EU. ${ }^{67}$ However, this rule remains dormant. In practice, to fill in the gap, Ukrainian laboratories use regulations approved by Soviet authorities that formally apply in the territory of Ukraine as long as they cover issues not regulated by Ukrainian legislation and do not contradict the Constitution and the laws of Ukraine. ${ }^{68}$ As a result, based on the old Soviet standards and regulations many of which date back to the 196os or even 1950s, Ukrainian laboratories demand kilos and kilos of samples for analysis. Businesses also complain about abolishing of the old state quality standards (so-called GOSTs) without substituting them with the new alternatives, a situation that does not allow selling respective aquaculture products legally.69 Producers demand the introduction of modern European standards for examination, stressing that modern technologies allow conclusive qualitative analysis by using only grams of the analyzed product. ${ }^{70}$ The Association Agreement contains obligations for Ukraine to implement the EU acquis related to food safety and quality control of some crops, animal meat and poultry, but, unfortunately, it is silent on fish and other aquatic organisms and products received from them. Numerous aquaculture industry requests to the government to change the status quo have fallen on deaf ears.

65 "Khto zupynyt derzhavny reket u rybnytstvi? [Who Will Stop State Racketeering in Fisheries?]."

66 MDETA can approve margin quantities of specimen collection based on Article 6(1) of the Law on the State Control of Compliance with the Legislation on Foods, By-Products of Animal Origin, Health and Well-Being of Animals.

67 Article 21(1) of the Law on the State Control of Compliance with the Legislation on Foods, By-Products of Animal Origin, Health and Well-Being of Animals.

68 This principle is embedded in Postanova Verkhovnoyi Rady Ukrainy "Pro poriadok tymchasovoi dii na teritorii Ukrainy okremykh aktiv zakonodavstva Soiuzu RSR” No. 1545-XII vid 12 veresnia 1991 roku [The resolution of Verkhovna Rada of Ukraine on the Procedure of Provisional Application of Certain Legislative Acts of the Union of Soviet Socialist Republics in the Territory of Ukraine No. 1545-XII of September 12, 1991], Vidomosti Verkhovnoi Rady Ukrainy, 1991, No. 46, St. 621.

69 "Khto zupynyt derzhavny reket u rybnytstvi? [Who Will Stop State Racketeering in Fisheries?]". 


\section{(3) Customs Problems, Expensive Feed and Absence of Capital for Development}

Inefficient customs procedures at Ukrainian borders represent another serious problem for aquaculture producers. First, laboratories responsible for controls and examination of imported goods use obsolete equipment and technologies. This, plus the State Customs Service of Ukraine's failure to distinguish between living and nonliving products, and widespread corruption, ${ }^{71}$ causes significant delays with fries on their way to their destination. ${ }^{72}$ In other words, it is not uncommon for fries, fish eggs and other hydrobionts ${ }^{73}$ to die during the prolonged customs inspection and laboratory examination. The Customs Code of Ukraine ${ }^{74}$ provides for "priority" customs clearance of goods such as live animals or goods with special qualities with a limited shelf life..$^{75}$ But priority customs clearance in Ukraine does not mean expedient clearance. Given that the veterinary inspection and sometimes food safety control must take place at the customs facilities, priority clearance remains a nothing more than a stated norm; it is not a warranty for an aquaculture importer. ${ }^{76}$ Aquaculture producers often confess that they have to resort to smuggling instead of acting lawfully.77

Aquacultural producers often must feed the products they produce. Ukraine does not have good facilities for feedstuffs production; therefore, aquaculture producers must buy foreign feed. Importing this feed increases their costs because a 10 per cent customs duty is imposed on imported fish feed. Aquaculture producers complain that feedstuffs represent their main expenditure, often accounting for 50-6o per cent of their total operating expenses. ${ }^{78}$ Nevertheless, even after numerous individual businesses and business associations complained in 2017 and 2018, the government of Ukraine increased the rate from 7.5to its current 10 per cent. Aquaculture producers feel discriminated against compared to importers of frozen fish whose imports are charged at o per cent rate. The imported feed is not a product for final consumption. Instead, it represents the necessary material for further production of a final aquaculture

\footnotetext{
71 See Aquaculture Development in Ukraine, 29.

72 I bid. 29.

73 Organisms living in water.

74 Mytnyi kodeks Ukrainy vid 13 bereznia 2012 roku z nastupnymy zminamy i dopovnenniamy [Customs Code of Ukraine of March 13, 2012 as amended], accessed May 4, 2020, https://zakon. rada.gov.ua/laws/show/4495-17.

75 Article 36 o.

76 Aquaculture Development in Ukraine, 87.

77 Ibid, 29; "Dmytro Zahumennyi: Ukraina mozhe staty eksporterom pereroblenoi ryby No. $1 \mathrm{v}$ YES [Dmytro Zahumennyi: Ukraine Can Become Exporter No. 1 of Processed Fish to EU]," September 26, 2018, accessed May 4, 2020, https://agravery.com/uk/posts/show/dmitro-zagumennij-ukraina-moze-stati-eksporterom-pereroblenoi-ribi-no1-u-es.

78 Aquaculture Development in Ukraine, 29-32.
} 
product. ${ }^{79}$ Moreover, the status quo contradicts the Law on Aquaculture which states that the state policy on aquaculture shall be implemented by means of creating equal conditions for competition between different aquaculture businesses. ${ }^{80}$ In contrast to Ukraine's actions, Poland abolished its customs duties for fish feeds used for predatory fish (sturgeon, trout, carp) in 2016. ${ }^{81}$

Since most of Ukraine's aquaculture facilities were constructed more than 30 years ago, the renovation of existing facilities or the construction of new ones and the, introduction of new technological solutions is an ever-present concern for producers. Lease payments for the rent of hydrotechnical facilities, technological reservoirs, and other water bodies are rather high but still they cannot cover the necessary renovation and maintenance costs, not to mention new construction. ${ }^{82}$ Cheap bank loans are not available for aquaculture producers, bank loan interest rates are as high as 25 per cent and no insurance available. ${ }^{83}$ Thus, potential investors see no incentives to contribute their available capital, and banks are unwilling to provide loans since aquaculture businesses cannot get insurance. During the Soviet, those problems were solved through strong state aid. Today, however, Ukrainian businesses cannot hope to successfully face the challenge alone.

\section{(4) State Support: Theory and Practice}

By signing the Association Agreement, Ukraine committed itself to adjust its national laws on state aid with the EU acquis. By analogy with the Treaty on Functioning of the European Union (TFEU), ${ }^{84}$ the Association Agreement states that any aid granted by Ukraine using state resources that distorts or threatens to distort competition by favoring a certain undertaking or the production of certain goods is incompatible with the proper functioning of the association if it may affect trade between Ukraine and the EU. ${ }^{85}$ In other words, state aid to businesses is treated per se as distorting free market and competition and is therefore prohibited. There are exceptions, such as aid

79 Lyst-zvernennia do holovy DARG Ukrainy vid 19 zhovtnia 2018 roku [Letter-Appeal to the Head of the State Agency of Fisheries of Ukraine of October 19, 2018], accessed May 4, 202O, https:// www.uas.net.ua/2018/10/23/\%D॰\%BB\%D॰\%B8\%D1\%81\%D1\%82-\%D॰\%B7\%D॰\%B2\%D॰\%B 5\%D1\%8。\%D॰\%BD\%D॰\%B5\%D॰\%BD\%D॰\%BD\%D1\%8F-\%D॰\%B4\%D॰\%BE-\%D॰\%B3\%D ○\%BE\%D॰\%BB\%D॰\%BE\%D॰\%B2\%D॰\%B8-\%D॰\%B4\%D॰\%B॰\%Dı\%8०\%D॰\%B3-\%Di\%83 \%D॰\%BA\%Dı\%8०\%D॰\%B॰\%Di\%97\%D॰\%BD\%D॰\%B8/.

80 Article 4 .

81 Aquaculture Development in Ukraine, 20.

82 Ibid., 31, 33 .

83 Ibid., 30-31, 72.

84 Consolidated Version of the Treaty on Functioning of the European Union as of October 26, 2012 (2012) OJ C326, 47.

85 Article 107(1) TFEU, Article 262(1) AA. 
to compensate for damage caused by natural disasters or exceptional occurrences; ${ }^{86}$ aid to promote the execution of important projects in the common European interest or to remedy a serious disturbance in the economy of Ukraine; aid to facilitate the development of certain economic activities or of certain economic areas where such aid does not adversely affect trading conditions contrary to the interest of the EU and Ukraine; aid to promote culture and heritage conservation; aid to promote objectives allowed under the EU horizontal block exemption regulations and horizontal and sectoral state aid rules granted in line with the conditions stated therein; and aid for investment to comply with the mandatory standards of the EU directives listed in annex XXIX to Chapter 6 (Environment) of Title V of the Association Agreement. 87 Within three years of that Agreement's entry into force, ${ }^{88}$ Ukraine was required to adopt national state aid legislation and to establish an operationally independent authority entrusted with the powers necessary for the full application of its treaty obligations. ${ }^{89}$ In short, Ukraine had to create a domestic analogue of the EU Commission to deal with state aid cases based on Article 108 of the TFEU. All new state aid in Ukraine had to comply with the requirements set out in the Association Agreement. ${ }^{90}$ Unlike other parts of that Agreement, its provisions on state aid do not contain detailed lists of the EU acquis to be implemented by Ukraine. Nevertheless, provisions on state aid must be applied using as sources of interpretation the criteria arising from the application of TFEU Articles 106, 107 and 93, including the relevant jurisprudence of the Court of Justice of the EU, as well as secondary legislation, frameworks, guidelines and other administrative acts in force in the EU.91

The Association Agreement's provisions on state aid ${ }^{92}$ did not become an absolute copy of the TFEU. The Association Agreement applies to goods and services that have been listed therein in accordance with the mutually agreed decision on market access, with the exception of subsidies to products covered by Annex 1 to the World Trade Organization (WTO) Agreement on Agriculture ${ }^{93}$ and other subsidies covered by the Association Agreement. ${ }^{94}$ Thus, unlike the EU acquis, state aid to agricultural producers was excluded from the scope of Association Agreement in particular and from the state aid laws in general.

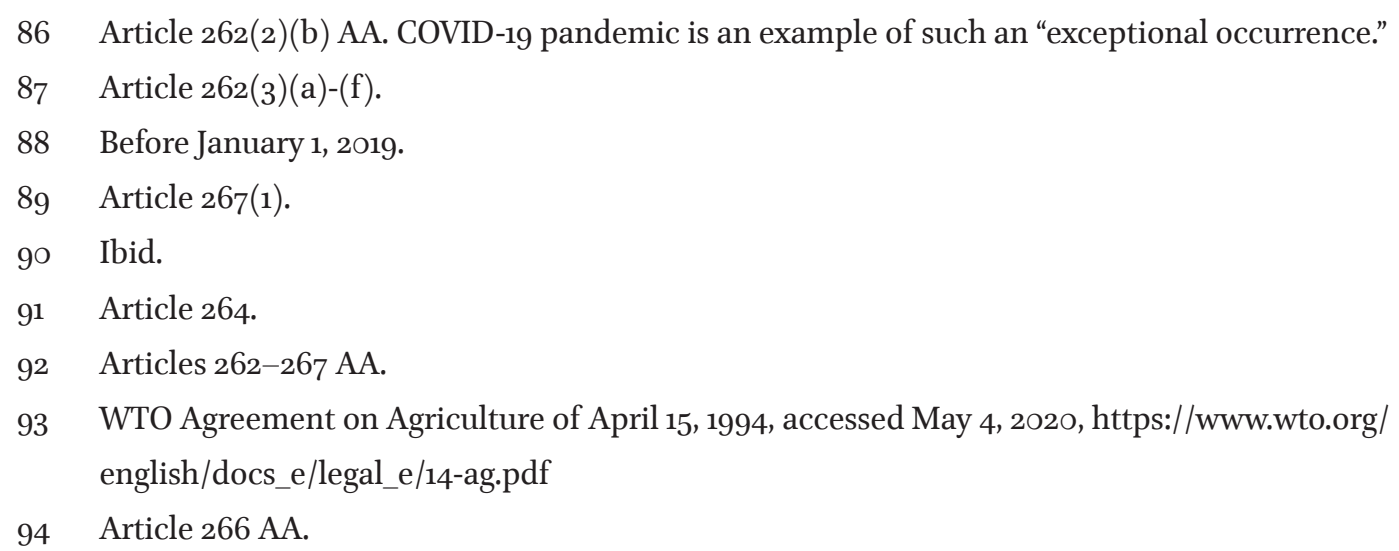


On July 1, 2014, the Verkhovna Rada of Ukraine adopted the Law on State Aid to Businesses $^{95}$ that entered into force on August 2, 2017. The Anti-Monopoly Committee of Ukraine has been nominated to serve as an operationally independent authority entrusted with the powers to monitor state aid, to conduct investigations and to make final decisions on such aid. ${ }^{96}$ State aid to agriculture and fisheries was excluded from the scope of the Law, and the Anti-Monopoly Committee does not deal with those sectors. ${ }^{97}$ This is more than controversial. In my opinion, it contradicts Ukraine's obligations under the Association Agreement. Whereas fish and fish products are explicitly excluded from Annex 1 to the WTO Agreement on Agriculture, the wording of the provisions of the Law on State Aid to Businesses does not correspond with the wording of the Association Agreement. ${ }^{98}$ According to the official commentaries provided by the Anti-Monopoly Committee on the question whether the Law on State Aid to Businesses covers cases of state aid granted to agricultural producers, fisheries and aquaculture producers had been excluded from the scope of the Law based on the provisions of the Association Agreement's Article 410 because "fish products have special regime in the TFEU as agricultural products." ${ }^{99}$ Reference to the Agreement's Article 410 is questionable since the latter determines that Ukraine and the EU

will support initiatives, such as mutual exchange of experience and providing support, designed to ensure the implementation of a sustainable fisheries policy based on priority areas in the EU acquis in this field, including:

(a) management of living aquatic resources, fishing effort and technical measures;

(b) inspection and control of fishing activities, using the necessary surveillance equipment, including a vessel monitoring system, as

Zakon Ukrainy "Pro derzhavnu dopomohu subiektam hospodariuvannia” vid 1 lypnia 2014 roku z nastupnymy zminamy i dopovnenniamy [The Law of Ukraine on State Aid to Businesses of July 1, 2014 as amended], accessed May 4, 2020, https://zakon.rada.gov.ua/laws/show/1555-18.

96 Article 8 of the Law on State Aid to Businesses.

97 Article 3(2).

98 Olha Kulyk, Systema derzhavnoi dopomohy v Ukraini: iak evropeiski vymohy mozhut zrobyty ii bilsh efektyvnoiu [System of State Aid in Ukraine: How European Requirements Can Make It More Efficient] (Kyiv: Ukrainskyi tsentr ievropeiskoi polityky, 2019), 41, accessed May 4, 2020, https://www.civic-synergy.org.ua/wp-content/uploads/2018/o4/Systema-derzhavnoyidopomogy-v-Ukrayini_yak-yevropejski-vymogy-mozhut-zrobyty-yiyi-bilsh-efektyvnoyu-1.pdf. Roziasnennia Antymonopolnoho komitetu Ukrainy z pytan zastosuvannia zakonodavstva u sferi derzhavnoi dopomohy No .1-pp/dd vid 4 sichnia 2018 roku [Commentaries of the Anti-Monopoly Committee of Ukraine on Matters of Application of State Aid Legislation of January 4, 2018 No. 1-pp/dd], accessed May 6, 2020, https://amcu.gov.ua/storage/app/sites/1/Docs/ rozijasnrnnia_u_sferi_derzhavnoi_dopomogy/rozyasnenya2.pdf. 
well as development of corresponding administrative and judicial structures capable of applying appropriate measures;

(c) harmonised collection of catch, landing, fleet, biological and economic data;

(d) management of fishing capacity, including a functioning fishing fleet register;

(e) improving the efficiency of the markets, in particular by promoting producer organisations, providing information to consumers, and through marketing standards and traceability; [and]

(f) development of a structural policy for the fisheries sector, paying particular attention to the sustainable development of coastal communities. ${ }^{100}$

Where and how the Association Agreement's Article 410 excludes fisheries and aquaculture products from it and how the TFEU contains a similar exclusion related to state aid remains a mystery known perhaps to the Anti-Monopoly Committee of Ukraine only. In the EU, state aid to aquaculture and fisheries is subject to the rules on state aid to the extent determined by the European Parliament and the Council in line with TFEU Articles 42 and 43. In practical terms this means that any funding granted by an EU Member State to the aquaculture and/or fishery industry other than co-financing under the framework of the European Maritime and Fisheries Fund (EMFF) shall be considered state aid. Therefore, the applicable rules of the EU acquis shall apply, and, upon notification regarding each state aid measure, the European Commission delivers the final decision to the Member State in question. The EU block exemption regulation for the fisheries and aquaculture industry ${ }^{101}$ exempts from the general rules on state aid certain kinds of aid (e. g. loans, guarantees, tax measures, and, in particular, repayable advances) granted to small and medium-sized enterprises (SMEs) active in the production, processing or marketing of fishery and aquaculture products. Also exempted is any aid granted to undertakings active in the production, processing, or marketing of fishery and aquaculture products to compensate for damage caused by natural disasters independently of the size of the aid's beneficiary. ${ }^{102}$ State aid not exceeding EUR 30,00o to one recipient for any period not exceeding three years (de minimis aid) is allowed based on the so-called De Minimis Regulation. ${ }^{103}$

100 Article 410 AA.

101 Commission Regulation (EU) No 1388/2014 of 16 December 2014 declaring certain categories of aid to undertakings active in the production, processing and marketing of fishery and aquaculture products compatible with the internal market in application of Articles 107 and 108 of the Treaty on the Functioning of the European Union (2014) OJ L 369, 37.

102 Article 1(1)(2) of the Regulation No 1388/2014.

103 Commission Regulation (EU) No 717/2014 of 27 June 2014 on the application of Articles 107 and 108 of the Treaty on the Functioning of the European Union to de minimis aid in the fishery 
Notwithstanding the exceptions, EU Member States must submit annual reports to the European Commission and disclose all state aid measures (including those granted as exceptions). Detailed analysis of Ukraine's obligations on state aid arising from the relevant provisions of the Association Agreement, the WTO Agreement on Agriculture, and other international treaties that might apply is beyond the scope of this article. It will suffice to say, however, that Ukraine's current state aid to aquaculture producers is so insignificant that it can hardly affect trade between the EU and Ukraine and trigger any consequences for non-compliance with the Association Agreement and the applicable acquis.

Since agriculture and aquaculture in particular are excluded from the scope of application of the Law on State Aid to Businesses, they are covered by the framework Law on the State Support of Agriculture of Ukraine.104 The Law explicitly mentions fish farmers and breeders among the potential recipients of state aid.105 The Law itself is obsolete and no longer grants any specific aid to producers. However, it describes various possible instruments that can be used by the central Ukrainian government and/ or local authorities as state aid measures. Funds for state aid to agriculture producers are normally allocated by the state budget that is approved annually by the Verkhovna Rada, while the Cabinet of Ministers of Ukraine deals with the rules on distribution of the funds allocated.106 The respective ministry in charge of agricultural sector, the MDETA, deals with individual cases of granting state aid based on applications submitted by potential recipients.

As explained above, the aquaculture industry has never been regarded as a priority in Ukraine's total agriculture production. Unlike farmers engaged in livestock breeding, growing various crops, and honey producers, Ukrainian aquaculture businesses have never been recipients of state aid until recently. The very word "aquaculture" first appeared in the state budget and applicable by-laws on state aid only in 2018. But the possibility for an aquaculture producer to receive state aid has been finally embedded in two governmental resolutions, namely the Resolution of the Cabinet of Ministers No. 106 of February 7, 2018 on the Approval of Rules for Utilization of Funds Allocated in the State Budget for Financial Support of Development of Farms (hereinafter - Resolution No. 106), ${ }^{107}$ and the Resolution of the Cabinet of Ministers No. 107 of February 7, 2018 on

and aquaculture sector (2014) OJ L 190, 45 .

104 Zakon Ukrainy "Pro derzhavnu pidtrymku silskoho hospodarstva Ukrainy vid 24 chervnia 2004 roku" z nastupnymy zminamy i dopovnenniamy [The Law of Ukraine on the State Support of Agriculture of Ukraine of June 24, 2004 as amended], accessed on May 4, 2020, https://zakon. rada.gov.ua/laws/show/1877-15.

105 Para $2.15^{-1}$ of Article 2.

106 Article 2O(7) of the Budget Code of Ukraine, see Biudzhetnyi kodeks Ukrainy vid 8 lypnia 2010 roku z nastupnymy zminamy i dopovnenniamy [Budget Code of Ukraine of July 8, 2010 as amended], accessed May 4, 2020, https://zakon.rada.gov.ua/laws/show/2456-17\#n417.

107 Postanova Kabinetu Ministriv Ukrainy "Pro zatverdzhennia Poriadku vykorystannia koshtiv, peredbachenyh u derzhavnomu biudzheti dlia nadannia finansovoi pidtrymky rozvytku 
the Approval of Rules for Utilization of Funds Allocated in the State Budget for Support of Livestock Farming, Storage and Processing of Agricultural Products, Aquaculture (Fisheries) (hereinafter - Resolution No. 107).108In 2018, the Ukrainian Parliament allocated funds amounting to UAH 4.2 billion, and state aid could be granted based on one of the following support schemes:

1) state support to livestock farming, storage and processing of agricultural products, aquaculture;

2) financial support to agriculture producers;

3) financial support for the development of farms;

4) state support for the development of hop growing, young gardens, vineyards and berry plantations; and

5) financial support aimed at cheaper bank loans (up to 17 per cent of the bank loan interest could be compensated by the state).

In 2019, the amount was increased to UAH 5.9 billion (about EUR 203.45 million), and the list of the support schemes was extended to include loans to farms. ${ }^{109}$ The impressive amount of the allocated funds centered on the state support to livestock farmers and farms engaged in growing various crops, ${ }^{110}$ and, as of mid-November 2019, the state paid $45 \cdot 7$ per cent of the total amount allocated by the scheme. ${ }^{111}$ Given the bureaucratic complications related to the filing of applications to the MDETA, amendments made to resolutions No. 106 and No. 107, presidential and parliamentary elections in Ukraine in 2019, and the "optimization" of the state bodies of executive power in the fall of 2019, by November 2019 the MDETA had not completed most of

fermerskykh hospodarstv" No. 106 vid 8 liutogo 2018 roku z nastupnymy zminamy i dopovnenniamy [Resolution on the Approval of Rules for Utilization of Funds Allocated in the State Budget for Financial Support of Development of Farms No. 106 of February 8, 2018 as amended], accessed May 5, 2020, https://zakon.rada.gov.ua/laws/show/106-2018-\%D॰\%BF.

108 Postanova Kabinetu Ministriv Ukrainy "Pro zatverdzhennia Poriadku vykorystannia koshtiv, peredbachenykh u derzhavnomu biudzheti dlia pidtrymky tvarynnytstva, zberihannia ta pererobky silskohospodarskoi produktsii, akvakultury (rybnytstva)"No. 107 vid 8 liutogo 2018 roku z nastupnymy zminamy i dopovnenniamy [Resolution of the Cabinet of Ministers of Ukraine on the Approval of Rules for Utilization of Funds Allocated in the State Budget for Support of Livestock Farming, Storage and Processing of Agricultural Products, Aquaculture (Fisheries) No. 107 of February 8, 2018 as amended], accessed May 5, 2020, https://zakon.rada.gov.ua/laws/ show/107-2018-\%Do\%BF.

109 Tsiohorich na pidtrymku fermeriv spriamuvaly menshe tretyny peredbachenoi sumy [This Year Less than One Third of the Allocated Amount Actually Paid to Farmers], November 19, 2019, accessed May 5, 2020, https://www.ukrinform.ua/rubric-economy/2821028-cogoric-napidtrimku-fermeriv-spramuvali-mense-tretini-peredbacenoi-sumi.html.

11 UAH 3.5 billion in 2019, unfortunately no detailed information on the state aid awards by specific area of agriculture production available.

111 Tsiohorich na pidtrymku fermeriv spriamuvaly menshe tretyny peredbachenoi sumy [This Year Less than One Third of the Allocated Amount Actually Paid to Farmers]. 
the declared programs of state support. Some of the support schemes were only onethird complete. For example, financial support to agriculture producers (including compensations for the purchased equipment) was only 28.8 percent complete. ${ }^{112}$ Aquaculture producers complained that receiving aid was next to impossible for them. ${ }^{113}$ To make things even worse, in August 2018, an NGO named "The All-Ukrainian Agricultural Council” filed an administrative suit with the Circuit Administrative Court of the City of Kyiv demanding to invalidate the Resolution No. 106 and the Resolution No. 107. After more than a year of court proceedings, on December 10, 2019, the Sixth Appellate Administrative Court invalidated both of the resolutions effective as of the moment of their adoption on February 7, 2018.114 The court justified its decision by pointing out violations of the Rules of Procedure (Rehlament) of the Cabinet of Ministers of Ukraine during the adoption of both resolutions. ${ }^{115}$ The MDETA appealed, and the case is pending at the Supreme Court of Ukraine. In practical terms, according to MDETA reports, the court decision of December 10, 2019, resulted in about UAH 1 billion being blocked on the treasury accounts (UAH 830 million for state support to livestock farming, storage and processing of agricultural products, aquaculture and UAH 186 million of financial support for the development of farms), and the ministry had to suspend all payments. The Supreme Court, however, unblocked the funds in late December 2019, and payments were resumed. ${ }^{116}$ The MDETA reported that in 2019 a total of UAH 4.34 billion had been used by the recipients of state aid.117

In 2020, the Law on the State Budget for 2020 allocated UAH 4.2 billion for state aid to agriculture, making the following state aid schemes possible:

\footnotetext{
112 Ibid.

113 “Khto zupynyt derzhavny reket u rybnytstvi? [Who Will Stop State Racketeering in Fisheries?]."

114 Postanova shostoho apeliatsiinoho administratyvnoho sudu vid 10 grudnia 2019 roku u spravi no. 826/13664/18 [Writ of the Sixth Appellate Administrative Court of December 10, 2019 in case No. 826/13664/18], accessed May 5, 2020, http://reyestr.court.gov.ua/Review/86273570. Ibid.

1163,4 mlrd hryven derzhavnoi pidtrymky otrymaiut agrarii u 2019 rotsi [3.4 Billion Will Be Received by Agriculture Producers in 2019], December 27, 2019, accessed May 5, 2020, https://www.me.gov.ua/News/Detail?lang=uk-UA\&id=74440381-5246-4bc5-86cb$\mathrm{f}_{5} \mathrm{f}_{3} \mathrm{e} 896 \mathrm{bf} 73$ \&title=3-4-MlrdGrivenDerzhavnoiPidtrimkiOtrimaiutAgrariiU2O19-Rotsi; Sud rozblokuvav maizhe milliard dotatsiy agrariiam [Court Unblocked Almost UAH 1 billion For Agriculture Subsidies], December 29, 2019, accessed May 5, 2020, https://www.epravda.com.ua/ news/2019/12/29/655419/.

117 Derzhpidtrymka agrariiv 2020: kredyty, tvarynnytstvo, fermerstvo, tekhnika, sadivnytstvo [State Support of Agricultural Producers 2020: Loans, Livestock Farming, Farming, Machinery, Gardening], February 25, 2020, accessed May 5, 2020, https://agropolit.com/ spetsproekty/694-derjpidtrimka-agrariyiv-2020-krediti-tvarinnitstvo-fermerstvo-tehnikasadivnitstvo; Derzhpidtrymka silhospvyrobnykiv-2020: perspektyvy [State Support Of Agricultural Producers - 2020: Prospects], accessed May 5, 2020, https://interbuh.com.ua/ua/documents/ $\mathrm{ib} / 10073 / 137788$.
} 
1) financial support for the development livestock farming and processing of agricultural products (UAH 1 billion);

2) financial support for the development of agricultural farms (UAH 400 million);

3) partial refund of costs paid for agricultural machinery and equipment made in Ukraine (UAH 1 billion);

4) financial support aimed at cheaper bank loans (UAH 1.5 billion); and

5) state support for the development of hop growing, young gardening, and vineyards (UAH 400 million).

In February 2020, the MDETA announced that payments would start in mid2020 based on approved applications submitted by potential recipients to the MDETA Ministerial Commission on State Aid. ${ }^{118}$ The government still needs to adopt by-laws similar to resolutions No. 106 and No. 107. The COVID-19 pandemic could have required adjustments to the state aid for Ukrainian agriculture producers because different versions of the draft law on amending the state budget for 2020 contained proposals to cancel the allocation of any funds for state aid to agriculture producers. Luckily for these producers, on April 13, 2020, amendments were adopted without funding reductions for agriculture. ${ }^{19}$ However, given the fragile situation in the Ukrainian economy due to the pandemic lockdown and the "national tradition" of frequent amendments and adjustments of the budgetary expenditures, it remains unknown what the future holds for state funding and other support for aquaculture producers.

On March 19, 2O2O, to enable EU Member States to use the full flexibility foreseen by the TFEU and state aid rules, the European Commission adopted a Temporary Framework for State Aid Measures to Support the Economy in the Current COVID-19 Outbreak. ${ }^{20}$ The Commission especially focused on agriculture (including businesses

118 Derzhpidtrymka agrarïv 2020: kredyty, tvarynnytstvo, fermerstvo, tekhnika, sadivnytstvo [State Support of Agricultural Producers 2020: Loans, Livestock Farming, Farming, Machinery, Gardening]; Nakaz Ministerstva rozvytku ekonomiky, torgivli ta silskoho hospodarstva Ukrainy "Pro zatverdzhennia Polozhennia pro Komisiiu Minekonomiky dlia nadannia derzhavnoi pidtrymky tvarynnytstva, zberihannia ta pererobky silskohospodarskoii produktsii, akvakultury (rybnytstva) ta form vidpovidnykh dokumentiv" No. 449 vid 28 lystopada 2019 roku [MDETA Order on the Approval of Regulations on the Ministerial Commission for Allocating State Support of Livestock Farming, Storing and Processing of Agricultural Products, Aquaculture (Fisheries) and Forms of Respective Documents No. 449 of November 28, 2019], accessed May 5, 2020, https://zakon.rada.gov.ua/laws/show/z1194-19.

119 Zakon Ukrainy "Pro vnesennia zmin do Zakony Ukrainy "Pro Derzhavnyi Biudzhet na 2020 rik" vid 13 kvitnia 2020 roku [The Law of Ukraine on Amending the Law on the State Budget of Ukraine for 2020 of April 13, 2O2O], accessed May 5, 2020, https://zakon.rada.gov.ua/laws/show/5532o\#n5.

Communication from the Commission of March 19, 2020 on Temporary Framework for State aid measures to support the economy in the current COVID-19 outbreak 2020 (2020) OJ C91, 1; Communication from the Commission of April 3, 2020 on Amendment to the Temporary 
engaged in fisheries and aquaculture) and provided for the following types of aid that can be granted by Member States to aquaculture producers until December 31, 2020:

i) Direct grants, equity injections, selective tax advantages and advance payments of up to EUR 120,00o per company to address urgent liquidity needs. Member States can also give, up to the nominal value of EUR 120,000 per company, zerointerest loans or guarantees on loans covering 100 per cent of the risk; ${ }^{121}$

ii) State guarantees for loans to companies to ensure that banks keep providing loans to the customers who need them. These state guarantees can cover up to go percent of the risk on loans to help businesses cover immediate working capital and investment needs; ${ }^{122}$

iii) Subsidized public loans to companies atfavorable interest rates. These loans can help businesses cover immediate working capital and investment needs; ${ }^{123}$

iv) Safeguards for banks that channel state aid to the real economy that such aid is considered as direct aid to the banks' customers (aquaculture producers), not to the banks themselves, and guidance on how to ensure minimal distortion of competition between banks; ${ }^{124}$

v) Public short-term export credit insurance for all countries, without the need for a Member State to demonstrate that the respective country is temporarily "nonmarketable"; 125

vi) Targeted support in the form of deferral of tax payments and/or suspensions of social security contributions for those sectors, regions, or types of companies that are hit the hardest by the outbreak; 126

vii) Targeted support in the form of wage subsidies for employees for those companies in sectors or regions that have suffered the most from the coronavirus outbreak and would otherwise have had to lay off personnel.127

An extraordinary situation with the COVID-19 pandemic, however, does not relieve Member States intending to introduce a respective state aid scheme from an obligation to notify the Commission accordingly, and the Commission can still decide that such a scheme is incompatible with the TFEU. ${ }^{128}$ In April 2020, the Commission approved EUR 4 million for Croatian and EUR 20 million for Portuguese state aid

Framework for State aid measures to support the economy in the current COVID-19 outbreak

(2020) OJ C112, 1.

121 Para 23(a).

122 Paras 24-25.

123 Para 27.

124 Paras 28-31.

125 Paras $32-33$.

126 Paras 40-41 as amended.

127 Paras 42-43 as amended.

128 Paras 44-48. 
schemes designed to support aquaculture and fisheries businesses. ${ }^{129}$ In the summer of 2020, Italy and Lithuania followed suit with their support schemes for EUR 1.2 billion and EUR 47.5 million, respectively. ${ }^{130}$ The list of possible state aid measures is more extensive than is possible than Ukraine's financial capabilities will allow. Ukrainian aquaculture producers cannot expect similar aid from their government any time soon, and yet there is much to be learned by Ukrainian law and policymakers from the EU experience.

\section{Conclusions}

Aquaculture producers in Ukraine are challenged by various policy inconsistencies and legal problems. The government's general attitude toward the industry cannot be called favorable. The Fall 2019 "optimization" within the structure of bodies of executive power did not make state management of the sector any easier or more transparent. Instead, it created new problems for the industry. Obtaining the necessary permits represents a significant obstacle for businesses intending to cultivate aquaculture. They have to deal with numerous authorities responsible for various permits, approvals, and certifications - the State Water Resources Agency, the State Agency of Fisheries, the Cabinet of Ministers of Ukraine, local municipal authorities, owners of land plots, various state enterprises, veterinary control, the State Service of Ukraine on Food Safety and Consumer Protection, to name but a few. Inconsistencies in the existing legislation and the impossibility of rent a part of a water body are among other problems faced by the aquaculture industry. The greedy "appetites" of veterinary and food-safety control agencies once the producer has managed to obtain the final product and wants to sell it to a consumer, expensive feeds and problems with the State Customs Office, and difficulties with obtaining much-needed state aid can explain why aquaculture's output has dropped so dramatically compared to the 1980s and why poaching and black aquaculture markets are thriving in Ukraine. In 2019, the total aquaculture output in Ukraine dropped by 1,589 tons (see Table 1 above) and fish imports increased by

129 State Aid: Commission approves $€ 4$ million Croatian direct grant scheme to support fishery and aquaculture sector in coronavirus outbreak, April 17, 2020, accessed May 20, 2020, https:// ec.europa.eu/commission/presscorner/detail/en/IP_20_681; State aid:Commission approves $€_{20}$ million Portuguese credit line scheme to support fishery and aquaculture sector in coronavirus outbreak, April 8, 2020, accessed May 25, 2020, https://ec.europa.eu/commission/presscorner/ detail/en/ip_20_6og.

Support measures for undertakings carrying out activities in the agricultural, forestry, fishery and aquaculture sectors and the activities related thereto, in relation with the Covid-19 outbreak crisis, SA.57947 (2020), accessed September 12, 2020, https://ec.europa.eu/competition/elojade/ isef/case_details.cfm?proc_code=3_SA_57947; Temporary State Aid to economic entities active in agriculture and aquaculture facing economic difficulties during the outbreak of Covid-19, SA.57823(2020), https://ec.europa.eu/competition/elojade/isef/case_details.cfm?proc_code=3_ SA_57823. 
5.2 per cent compared to 2018,400 aquaculture businesses ceased to exist in $2019 .{ }^{131}$ And all this happened despite aquaculture's vital role in replenishment of the national water biological resources. ${ }^{132}$ This could have served as an additional argument for the necessity of state support of aquaculture and would have counterbalanced the environmental concerns that started to emerge in other countries in relation to aquaculture. ${ }^{133}$ It is too early to claim that Ukraine's aquaculture is dying, but the trend toward this in the available statistics should not be underestimated.

It would be naïve to expect that the government of Ukraine can drastically change the situation any time soon, for it requires complete revision of the existing legal base, professional competence and stability of the executive bodies responsible for the state policy in the field, special state aid programs aimed specifically at aquaculture producers, and the complete renovation of aquaculture infrastructure. And yet it is possible to start helping aquaculture now. First, this can be done by adopting amendments to the Law on Aquaculture together with the adoption of by-laws that would allow renting parts of water bodies for the needs of aquaculture. Second, a "single window" can be introduced to facilitate issuance of various permits and approvals so that to reduce bureaucracy, delays, and corruption. Third, abolishing of import duties on feeds will significantly reduce costs for producers and eventually reduce prices for consumers. Fourth, much needed EU standards for laboratory examination of aquaculture products can be introduced. Finally, more attention to aquaculture and its specifics needs compared to other agricultural producers should be considered when distributing state aid. If done properly, these measures will revive the industry, improve the national economy, restore biological resources, and contribute to Ukraine's general response to COVID-19 challenges.

131 Publichnyi zvit Derzhavnoho ahentstva rybnoho hospodarstva za 2018 rik [Public Report of the State Agency of Fisheries of Ukraine for 2018], 3, 5-6; Publichnyi zvit Derzhavnoho ahentstva rybnoho hospodarstva za 2019 rik [Public Report of the State Agency of Fisheries of Ukraine for 2019], 5, 8 .

132 Publichnyi zvit Derzhavnoho ahentstva rybnoho hospodarstva za 2019 rik [Public Report of the State Agency of Fisheries of Ukraine for 2019], 5 .

133 FAO notes that despite the unprecedented global developments in aquaculture industry "there have also been undesirable environmental impacts at the local, regional and global levels. These detrimental effects include social conflicts between users of land and aquatic resources (especially water), and the destruction of important ecosystem services. Moreover, recent aquaculture undertakings have raised concern and societal debate, especially with regard to: poor site selection; habitat destruction (e.g. of mangroves); the use of harmful chemicals and veterinary drugs; the impact of escapees on wild stocks; inefficient or unsustainable production of fishmeal and fish oil; and social and cultural impacts on aquaculture workers and communities," see The State of World Fisheries and Aquaculture 2020. Sustainability in Action (Rome: FAO, 202O), 124, accessed September 12, 2020, https://doi.org/10.406o/ca9229en. 


\section{Bibliography}

Aquaculture Development in Ukraine: Comprehensive Analysis of Challenges and Opportunities of Aquaculture Industry in Ukraine, Best-Practice Experience and Policy Recommendations (Kyiv: EasyBusiness, Norwegian-Ukrainian Chamber of Commerce, Everlegal, State Fisheries Agency of Ukraine, 2017), accessed April 30, 2020, https://www.slideshare.net/Easy_Business/aquaculture-developmentin-ukraine-83657826.

Association Agreement between the European Union and its Member States, of the one part, and Ukraine, of the other part, of 21 March 2014 (2014) OJ L 161, 3.

BiudzhetnyikodeksUkrainyvid 8lypnia 2010 rokuz nastupnymy zminamyidopovnenniamy [Budget Code of Ukraine of July 8, 2010 as amended], accessed May 4, 2020, https://zakon.rada.gov.ua/laws/show/2456-17\#n417.

Commission Regulation (EU) No. 717/2014 of 27 June 2014 on the application of Articles 107 and 108 of the Treaty on the Functioning of the European Union to de minimis aid in the fishery and aquaculture sector (2014) OJ L 190, 45.

Commission Regulation (EU) No. 1388/2014 of 16 December 2014 declaring certain categories of aid to undertakings active in the production, processing and marketing of fishery and aquaculture products compatible with the internal market in application of Articles 107 and 108 of the Treaty on the Functioning of the European Union (2014) OJ L 369, 37.

Communication from the Commission of April 3, 2020 on Amendment to the Temporary Framework for State aid measures to support the economy in the current COVID-19 outbreak (2O20) OJ C112, 1.

Communication from the Commission of March 19, 2020 on Temporary Framework for State aid measures to support the economy in the current COVID-19 outbreak 2020 (2020) OJ C91, 1.

Consolidated Version of the Treaty on Functioning of the European Union as of October 26, 2012 (2012) OJ C326, 47.

Deiaki pytannia optymizatsii systemy tsentralnykh organiv vykonavchoi vlady vid 27 travnia 2020 roku No. 425 [Some Issues of Optimization of the System of Central Bodies of Executive Power adopted by the resolution of the Cabinet of Ministers of Ukraine of May 27, 2020 No. 425], Ofitsiynyi Visnyk Ukrainy, 2020, No.45, St. 1449.

Derzhpidtrymka agrariiv 2020: kredyty, tvarynnytstvo, fermerstvo, tekhnika, sadivnytstvo [State Support of Agricultural Producers 2020: Loans, Livestock Farming, Farming, Machinery, Gardening], February 25, 2020, accessed May 5, 2020, https://agropolit. com/spetsproekty/694-derjpidtrimka-agrariyiv-2020-krediti-tvarinnitstvofermerstvo-tehnika-sadivnitstvo.

Derzhpidtrymka silhospvyrobnykiv-2020: perspektyry [State Support Of Agricultural Producers - 2020: Prospects], accessed May 5, 2020, https://interbuh.com.ua/ ua/documents/ib/10073/137788.

"Dmytro Zahumennyi: Ukraina mozhe staty eksporterom pereroblenoi ryby No. 1 V YES [Dmytro Zahumennyi: Ukraine Can Become Exporter No. 1 of Processed Fish to 
EU]," September 26, 2018, accessed May 4, 2020, https://agravery.com/uk/posts/ show/dmitro-zagumennij-ukraina-moze-stati-eksporterom-pereroblenoi-ribino1-u-es.

FAO's "Global Aquaculture Production (online query)," accessed April 30, 2020, http:// www.fao.org/fishery/statistics/global-aquaculture-production/query/en.

FAOSTAT: Commodities by Country (Exports), accessed April 30, 2020, http://www.fao. org/faostat/en/\#rankings/commodities_by_country_exports.

"Khto zupynyt derzhavny reket u rybnytstvi? [Who Will Stop State Racketeering in Fisheries?]," interview by Yuriy Yaremenko, AgroNews.ua, January 18, 2019, accessed April 30, 2020, https://agronews.ua/interview/khto-zupynyt-derzhavny-reket-urybnytstvi/.

Joint Statement on COVID-19 Impacts on Food Security and Nutrition (FAO, IFAD, the World Bank and WFP on the occasion of the Extraordinary G2O Agriculture Minister's Meeting, April 2O, 2020), accessed April 30, 2020, http://www.fao.org/ news/story/en/item/1272058/icode/.

Kulyk, Olha, Systema derzhavnoi dopomohyv Ukraini: iak evropeiski vymohy mozhut zrobyty ii bilsh efektyvnoiu [System of State Aid in Ukraine: How European Requirements Can Make It More Efficient] (Kyiv: Ukrainskyi tsentri evropeiskoi polityky, 2019), 41, accessed May 4, 2020, https://www.civic-synergy.org.ua/wpcontent/uploads/2018/o4/Systema-derzhavnoyi-dopomogy-v-Ukrayini_yakyevropejski-vymogy-mozhut-zrobyty-yiyi-bilsh-efektyvnoyu-1.pdf.

Lyst-zvernennia do holovy DARG Ukrainy vid 19 zhovtnia 2018 roku [Letter-Appeal to the Head of the State Agency of Fisheries of Ukraine of October 19, 2018], accessed May 4, 2020, https://www.uas.net.ua/2018/10/23/\%D॰\%BB\%D॰\%B8\%D1\%81 \%D1\%82-\%D॰\%B7\%D॰\%B2\%D॰\%B5\%D1\%8॰\%D॰\%BD\%D॰\%B5\%D॰\%BD \%D॰\%BD\%Dı\%8F-\%D॰\%B4\%D॰\%BE-\%D॰\%B3\%D॰\%BE\%D॰\%BB\%D॰\%B E\%D॰\%B2\%D॰\%B8-\%D॰\%B4\%D॰\%B॰\%D1\%8○\%D॰\%B3-\%D1\%83\%D॰\%B A\%D1\%8०\%D॰\%B०\%D1\%97\%D॰\%BD\%D॰\%B8/.

Mytnyi kodeks Ukrainy vid 13 bereznia 2012 roku z nastupnymy zminamy i dopovnenniamy [Customs Code of Ukraine of March 13, 2012 as amended], accessed May 4, 2O2O, https://zakon.rada.gov.ua/laws/show/4495-17.

Nakaz Ministerstva ekologii ta pryrodnykh resursiv Ukrainy vid 16 grudnia 2013 roku No. 742 "Pro zatverdzhennia poriadku rozroblennia pasporta rybohospodarskoi tekhnologichnoivodoimy" [Order of the Ministry of Ecology and Natural Resources of Ukraine of December 16, 2013, No. 742 on Approval of the Procedure of Fishery Technological Reservoir Passport Development], accessed May 2, 2020, https:// zakon.rada.gov.ua/laws/show/zoo27-14.

Nakaz Ministerstva ekologii ta pryrodnykh resursiv Ukrainy vid 18 bereznia 2013 roku No. 99 "Pro zatverdzhennia poriadku rozroblennia pasportu vodnoho obiektu" [Order of the Ministry of Ecology and Natural Resources of Ukraine of March 18, 2013 No. 99 on Approval of the Procedure of Water Object's Passport Development], accessed May 2, 2020, https://zakon.rada.gov.ua/laws/show/zo775-13. 
Nakaz Ministerstva rozvytku ekonomiky, torgivli ta silskoho hospodarstva Ukrainy "Pro zatverdzhennia Polozhennia pro Komisiiu Minekonomiky dlia nadannia derzhavnoi pidtrymky tvarynnytstva, zberihannia ta pererobku silskohospodarskoii produktsii, akvakultury (rybnytstva) ta form vidpovidnykh dokumentiv" No. 449 vid 28 lystopada 2019 roku [MDETA Order on the Approval of Regulations on the Ministerial Commission for Allocating State Support of Livestock Farming, Storing and Processing of Agricultural Products, Aquaculture (Fisheries) and Forms of Respective Documents No. 449 of November 28, 2019], accessed May 5, 2020, https://zakon.rada.gov.ua/laws/show/z1194-19.

Polozhennya pro Ministerstvo enerhetyky ta zakhystu dovkillya Ukrainy v redaktsiyi postanovy Kabinetu Ministriv Ukrainyvid 18 veresnya 2019 r. No. 847 [Charter of the Ministry of Energy and Environmental Protection of Ukraine as amended by the Resolution of the Cabinet of Ministers of Ukraine of September 18, 2019 No. 847], Ofitsiynyi Visnyk Ukrainy, 2019, No. 78, St. 2694.

Polozhennya pro Ministerstvo rozvytku ekonomiky, torhivli ta silskogo hospodarstva Ukrainy v redaktsiyi postanovy Kabinetu Ministriv Ukrainy vid 11 veresnya 2019 r. No. 838 [Charter of the Ministry for Development of Economy, Trade and Agriculture as amended by the Resolution of the Cabinet of Ministers of Ukraine of September 11, 2019 No. 838], Ofitsiynyi Visnyk Ukrainy, 2019, No. 74, St. 2588.

Postanova Kabinetu Ministriv Ukrainy "Pro zatverdzhennia Poriadku vykorystannia koshtiv, peredbachenyh u derzhavnomu biudzheti dlia nadannia finansovoi pidtrymky rozvytku fermerskykh hospodarstv" No. 106 vid 8 liutogo 2018 roku z nastupnymy zminamy $i$ dopovnenniamy [Resolution on the Approval of Rules for Utilization of Funds Allocated in the State Budget for Financial Support of Development of Farms No. 106 of February 8, 2018 as amended], accessed May 5, 2020, https://zakon.rada.gov.ua/laws/show/106-2018-\%Do\%BF.

Postanova Kabinetu Ministriv Ukrainy "Pro zatverdzhennia Poriadku vykorystannia koshtiv, peredbachenykh u derzhavnomu biudzheti dlia pidtrymky tvarynnytstva, zberihannia ta pererobky silskohospodarskoi produktsii, akvakultury (rybnytstva)" No. 107 vid 8 liutogo 2018 roku z nastupnymy zminamy i dopovnenniamy [Resolution of the Cabinet of Ministers of Ukraine on the Approval of Rules for Utilization of Funds Allocated in the State Budget for Support of Livestock Farming, Storage and Processing of Agricultural Products, Aquaculture (Fisheries) No. 107 of February 8, 2018 as amended], accessed May 5, 2020, https://zakon.rada.gov.ua/laws/ show/107-2018-\%Do\%BF.

Postanova Kabinetu Ministriv Ukrainy "Pro zatverdzhennya Typovoho dohovoru orendy vodnykh obiektiv" No. 420 vid 23 travnia 2013 roku z nastupnymy zminamy $i$ dopovnennyamy [the Resolution of the Cabinet of Ministers of Ukraine on Approval of Standard Lease Agreement of Water Objects No. 420 of May 29, 2013 as amended], accessed May 2, 2020, https://zakon.rada.gov.ua/laws/show/42O$2013-\%$ Do\%BF.

Postanova Kabinetu Ministriv Ukrainy vid 2 veresnya 2019 r. No. 829 "Deyaki Pytannya Optymyzatsiyi Systemy Tsentralnykh Orhaniv Vykonavchoyi Vlady" z nastupnymy 
zminamy i dopovnennyamy [Resolution of the Cabinet of Ministers of Ukraine of September 2, 2019 No. 829 on Some Issues Related to Optimization of Central Bodies of Executive Power as amended], accessed May 2, 2020, https://zakon.rada. gov.ua/laws/show/829-2019-\%D॰\%BF.

Postanova shostoho apeliatsiinoho administratyvnoho sudu vid 10 grudnia 2019 roku u spravi no. 826/13664/18 [Writ of the Sixth Appellate Administrative Court of December 10, 2019 in case No. 826/13664/18], accessed May 5, 2020, http://reyestr. court.gov.ua/Review/86273570.

Postanova Verkhovnoyi Rady Ukrainy "Pro poriadok tymchasovoi dii na teritorii Ukrainy okremykh aktiv zakonodavstva Soiuzu RSR” No. 1545-XII vid 12 veresnia 1991 roku [The resolution of Verkhovna Rada of Ukraine on the Procedure of Provisional Application of Certain Legislative Acts of the Union of Soviet Socialist Republics in the Territory of Ukraine No. 1545-XII of September 12, 1991], Vidomosti Verkhovnoi Rady Ukrainy, 1991, No. 46, St. 621.

Publichyi zvit Derzhavnoho ahentstva rybnoho hospodarstva Ukrainy za 2018 rik [Public report of the State Agency of Fisheries of Ukraine for 2018], accessed May 2, 2020, http://darg.gov.ua/_publichnij_zvit_derzhavnogo_o_o_o_8359_1.html.

Publichnyi zvit Derzhavnoho ahentstva rybnoho hospodarstva za 2019 rik [Public Report of the State Agency of Fisheries of Ukraine for 2019], accessed May 6, 202O, https:// www.kmu.gov.ua/storage/app/sites/1/17-civik-2018/zvit_2019/zvit-2019-fish.pdf.

Puls Uhody: monitorynh realizatsii planu zakhodiv z vykonannia Uhody (navkolyshne pryrodne seredovyshche ta tsyvilnyi zahyst) [Pulse of the Agreement: Monitoring of the Compliance with the Association Agreement Implementation Plan (Environment and Civil Defense), accessed May 2, 2020, http://reforms.in.ua/ua/ streams/environment.

"Produktsiia akvakultury za 2018 rik (Zvit 1-A (Ryba richna)) [Aquaculture Production in 2018" (Report 1-A (River Fish)]," accessed April 30, 2020, http://darg.gov.ua/_ virobnictvo_produkciji_o_223_menu_o_1.html.

"Produktsiia akvakultury za 2019 rik (Zvit 1-A (Ryba richna)) [Aquaculture Production in 2019 (Report 1-A (River Fish)]," accessed April 30, 2020, http://darg.gov.ua/_ virobnictvo_produkciji_o_223_menu_o_1.html.

"Reforms to Increase Production, Streamline Administration," Eurofish Magazine, 2016, no. $1,34-35$.

3,4 mlrd hryven derzhavnoi pidtrymky otrymaiut agrarii u 2019 rotsi [3.4 Billion Will Be Received by Agriculture Producers in 2019], December 27, 2019, accessed May 5, 2020, https://www.me.gov.ua/News/Detail?lang=uk-UA\&id=7444O381-52464bc5-86cb-f5f3e896bf 73 \& title=3-4-MlrdGrivenDerzhavnoiPidtrimkiOtrimaiut AgrariiU2019-Rotsi.

Rekomendatsii parlamentskykh slukhan na temu: "Priorytety ekolohichnoi polityky Verkhovnoi Rady Ukrainy na nastupni piat rokiv," zatverdzheni postanovoiu Verkhovnoi Rady Ukrainy vid 14 sichnia 2020 roku No. 457-IX [Recommendations of Parliamentary Hearings on the Topic "Priorities of Environmental Policy of 
Verkhovna Rada for the Following Five Years" approved by the Resolution of Verkhovna Rada of Ukraine of January 14, 2020 No. 457-IX], accessed May 2, 2020, https://zakon.rada.gov.ua/laws/show/457-20.

Roziasnennia Antimonopolnoho komitetu Ukrainy z pytan zastosuvannia zakonodavstva u sferi derzhavnoi dopomohy No. 1-pp/dd vid 4 sichnia 2018 roku [Commentaries of the Anti-Monopoly Committee of Ukraine on Matters of Application of State Aid Legislation of January 4, 2018 No. 1-pp/dd], accessed May 6, 2020, https://amcu. gov.ua/storage/app/sites/1/Docs/rozijasnrnnia_u_sferi_derzhavnoi_dopomogy/ rozyasnenya2.pdf.

Sharylo, Yu. Ye., "Problemy rozvytku suchasnoi akvakultury [Problems for Development of Modern Aquaculture]," accessed April 30, 2020, https://www.slideshare.net/ USAIDLEV/ss- 64585413 .

State Aid: Commission approves $€ 4$ million Croatian direct grant scheme to support fishery and aquaculture sector in coronavirus outbreak, April 17, 2020, accessed on May 20, 2020, https://ec.europa.eu/commission/presscorner/detail/en/IP_2O_681.

State aid: Commission approves $€ 20$ million Portuguese credit line scheme to support fishery and aquaculture sector in coronavirus outbreak, April 8, 2020, accessed May 25, 2020, https://ec.europa.eu/commission/presscorner/detail/en/ip_20_6o9.

Sud rozblokuvav maizhe milliard dotatsiy agrariiam [Court Unblocked Almost UAH 1 billion For Agriculture Subsidies], December 29, 2019, accessed May 5, 2020, https://www.epravda.com.ua/news/2019/12/29/655419/.

Support measures for undertakings carrying out activities in the agricultural, forestry, fishery and aquaculture sectors and the activities related thereto, in relation with the Covid-19 outbreak crisis, SA.57947 (2020), accessed September 12, 2020, https:// ec.europa.eu/competition/elojade/isef/case_details.cfm?proc_code=3_SA_57947. Symonenko, Konstyantyn, "Yakv Ukrayini Vidkryty Ustrychnu Fermu [How to Open an Oyster Farm in Ukraine]" (May 15, 2017), accessed April 30, 2020, https://news. finance.ua/ua/news/-/401586/yak-v-ukrayini-vidkryty-ustrychnu-fermu.

Temporary State Aid to economic entities active in agriculture and aquaculture facing economic difficulties during the outbreak of Covid-19, SA.57823 (2020), https:// ec.europa.eu/competition/elojade/isef/case_details.cfm?proc_code=3_SA_57823.

The State of World Fisheries and Aquaculture 2020. Sustainability in Action (Rome, FAO, 2O2O), accessed September 12, 2020, https://doi.org/10.406o/ca9229en.

Tsiohorich na pidtrymku fermeriv spriamuvaly menshe tretyny peredbachenoi sumy [This Year Less than One Third of the Allocated Amount Actually Paid to Farmers], November 19, 2019, accessed May 5, 2020, https://www.ukrinform.ua/rubric-economy/2821028-cogoric-na-pidtrimku-fermeriv-spramuvali-mense-tretini-peredbacenoi-sumi.html.

Vodnyi kodeks Ukrainy vid 6 chervnya 1995 rokuz nastupnymy zminamy i dopovnennyamy [Water Code of Ukraine of June 6, 1995 as amended], accessed May 2, 2020, https:// zakon.rada.gov.ua/laws/show/213/95-\%Do\%B2\%D1\%8o.

WTO Agreement on Agriculture of April 15, 1994, accessed May 4, 2020, https://www. wto.org/english/docs_e/legal_e/14-ag.pdf. 
Yaremenko, Yu. F., "Ryba v sitkah biurokrata [Fish in Bureaucrat's Nets]," Ekonomichna Pravda, August 15, 2019, accessed April 30, 2020, https://www.epravda.com.ua/ columns/2019/o8/15/650548/.

Yaremenko, Yu. F., "Nove ministerstvo pozbaryt akvakulturu enerhetyky [New Ministry Will Deprive Aquaculture of Energy]," Agro Times, October 19, 2019, accessed May 2, 2020, https://agrotimes.ua/opinion/nove-ministerstvo-pozbavyt-akvakulturu-energetyky/.

Zakon Ukrainy "Pro akvakulturu" vid 18 veresnia 2012 roku z nastupnymy zminamy $i$ dopovnennyamy [Law of Ukraine on Aquaculture of September 18, 2012 as amended], accessed April 30, 2020, https://zakon.rada.gov.ua/laws/show/5293-17.

Zakon Ukrainy "Pro derzhavnu dopomohu subiektam hospodariuvannia" vid 1 lypnia 2014 roku z nastupnymy zminamy i dopovnenniamy [The Law of Ukraine on State Aid to Businesses of July 1, 2014 as amended], accessed May 4, 2020, https://zakon.rada. gov.ua/laws/show/1555-18.

Zakon Ukrainy "Pro derzhavnu pidtrymku silskoho hospodarstva Ukrainy vid 24 chervnia 2004 roku" $z$ nastupnymy zminamy $i$ dopovnenniamy [The Law of Ukraine on the State Support of Agriculture of Ukraine of June 24, 2004 as amended], https:// zakon.rada.gov.ua/laws/show/1877-15.

Zakon Ukrainy "Pro derzhavnyi control za dotrymanniam zakonodavstva pro kharchovi produkty, pobichniprodukty tvarynnoho pokhodzhennia, zdorovia ta blahopoluchchia tvaryn" vid 18 travnia 2017 roku z nastupnymy zminamy i dopovnenniamy [the Law of Ukraine on the State Control of Compliance with the Legislation on Foods, By-Products of Animal Origin, Health and Well-Being of Animals of May 18, 2017 as amended], accessed May 3, 2020, https://zakon.rada.gov.ua/laws/show/2042-19.

Zakon Ukrainy "Pro osnovni zasady (strategiiu) derzhavnoi ekologichnoi polityky Ukrainy na period do 2030 roku" [The Law of Ukraine on the Fundamentals (Strategy) of the State Environmental Policy of Ukraine Until 2030], Vidomosti Verkhovnoi Rady Ukrainy, 2019, No. 16, St. 70.

Zakon Ukrainy "Pro rybne hospodarstvo, promyslove rybalstvo ta okhoronu vodnykh bioresursiv" vid 8 lypnia 2011 roku z nastupnymy zminamy i dopovnenniamy [The Law of Ukraine on Fisheries, Industrial Fisheries and Protection of Aquatic Biological Resources of July 8, 2011 as amended], accessed May 2, 2020, https:// zakon.rada.gov.ua/laws/show/3677-17.

Zakon Ukrainy "Pro rybu, inshi vodni zhyvi resursy ta kharchovu produktsiiu z nykh" vid 6 liutogo 2003 roku z nastupnymy zminamy i dopovnenniamy [The Law of Ukraine on Fish, Other Aquatic Biological Resources and Food Products from Them of February 6, 2003 as amended], accessed May 2, 2020, http://zakon4.rada.gov.ua/ laws/show $/ 55^{-2010-\% D o \% B F . ~}$

Zakon Ukrainy "Pro tvarynnyi svit" vid 13 hrudnia 2001 roku z nastupnymy zminamy I dopovnenniamy [The Law of Ukraine on the Animal World of December 13, 2001 as amended], accessed May 2, 2020, https://zakon.rada.gov.ua/laws/show/289414 . 
Zakon Ukrainy "Pro veterynarnu medytsynu" vid 25 chervnia 1992 roku z nastupnymy zminamy i dopovnenniamy [The Law of Ukraine on Veterinary Medicine of June 25, 1992 as amended], accessed May 2, 2020, https://zakon.rada.gov.ua/laws/ show/2498-12.

Zakon Ukrainy "Pro vnesenniazmin do ZakonyUkrainy "Pro DerzhavnyiBiudzhetna 2020 rik" vid 13 kvitnia 2020 roku [The Law of Ukraine on Amending the Law on the State Budget of Ukraine for 2020 of April 13, 2020], accessed May 5, 2020, https://zakon. rada.gov.ua/laws/show/553-20\#n5.

Zemelnyi kodeks Ukrainy vid 25 zhovtnya 2001 roku z nastupnymy zminamy $i$ dopovnennyamy [Land Code of Ukraine of October 25, 2001 as amended], accessed May 2, 2020, https://zakon.rada.gov.ua/laws/show/2768-14.

\section{(7)}

Oleksiy Kononov holds an SJD degree from Central European University, Budapest. His research interests include comparative law, international business law, international investment law, contract and corporate law, state aid law, European Union Law. He taught law-related subjects in the USA, Bosnia and Herzegovina, Sultanate of Oman and China. He also has experience of working as consultant for international development aid projects in Ukraine. 


\title{
Українська Національна Політика у Сфері Аквакультури: Реальність чи Міф?
}

\author{
Олексій Кононов \\ незалежний дослідник \\ Україна
}

\begin{abstract}
Анотація
Аквакультура є багатообіцяючим сектором української аграрної економіки, і могла б зробити свій внесок до національної продовольчої безпеки та допомогти подолати деякі виклики, спричинені пандемією COVID-19. Протягом багатьох років політика українського уряду стосовно аквакультури не була спрямована на їі підтримку, зокрема через те, що державне управління галуззю було розпорошене між різними міністерствами. Правове регулювання цього сектору $є$ надмірно зарегульованим, і виробники стикаються з численними труднощами з отриманням дозволів, питаннями оренди водних об'єктів, перевірками, митними питаннями та імпортом кормів. Угода про Асоціацію між Україною та Європейським Союзом не містить конкретних зобов'язань щодо аквакультури. Державна допомога виробникам аквакультури, які її конче потребують, залишається незначною і такою, яку складно отримати у порівнянні із допомогою, яка надається у інших аграрних сферах. Стаття присвячена аналізу основних політичних та правових проблем, з якими стикаються виробники аквакультури і пропонує рішення, які можуть покращити ситуацію.
\end{abstract}

Ключові слова: сільське господарство, аквакультура, рішення по COVID-19, рибництво, державна допомога, водні ресурси 